\title{
Effect of Cinnamon, Propolis ,or Their Combination on Blood Glucose, Body Weight, Feed Efficiency Ratio and Relative Organs' Weights in Rats with Diabetes Mellitus.
}

\author{
G.M.El-Kherbawy ${ }^{1}$, S.G.Noub ${ }^{2}$ and H.M.Abd El-Aziz ${ }^{3}$, S.A.Zaki ${ }^{1}$
}

\begin{abstract}
Since ancient times, cinnamon and propolis have been used as folk medicine with reported beneficial effects on various clinical conditions. According to previous studies cinnamon and propolis may have a positive effect on glycemic control in diabetes mellitus. The present investigation was assigned to study the effect of cinnamon, propolis ,or their combination on blood glucose levels, body weight, feed efficiency ratio, body weight gain, and relative organs' weights in diabetic rats compared to normal rats. Thirty male albino rats were randomly divided into two main groups. The first group $(n=6)$ was considered as negative control non diabetic rats (group 1). The other group of rats ( 24 rats) was subjected for intravenous injection with recrystalyzed alloxan to induce hyperglycemia. The diabetic rats were randomly assigned to four equal groups. (Group 2) alloxan induced, untreated rats $(n=6)$ were chosen as positive control and the other three groups (groups 3,4 and5) were given stomach tube with cinnamon, propolis ,or mixture of cinnamon and propolis, respectively. The concentration of dry material were $10 \mathrm{mg}$ cinnamon $/ \mathrm{ml}$, and $3 \mathrm{mg}$ propolis $/ \mathrm{ml}$ and mixture of $10 \mathrm{mg}$ cinnamon and $3 \mathrm{mg}$ propolis $/ \mathrm{ml}$ for groups 3,4 and 5 respectively intragastrically once daily for 6 weeks(all groups were fed the basal diet). The results showed that treatment of diabetic rats with cinnamon, propolis and their combination led to decrease in serum glucose levels, compared with diabetic control group. The best treatment that improved serum glucose level was the combination of cinnamon \&propolis. Regarding BWG\% and FER of rats, there were very highly significant differences between positive and negative control groups. Body weight of normal control group rats was significantly higher than the three treated groups as well as the FER. But there was no significant difference between CINN, PROP and CINN+PROP in BWG either in BWG\% or FER. There were no significant differences among the treated groups in liver weights. Also, there were insignificant differences among the mean values of relative weights for kidney, heart and spleen in the treated groups $(3,4 a n d 5)$.While, these values were significantly lower than those of diabetic control group. For relative brain weight, normal control group showed significantly higher value compared to the other groups. While, there were insignificant differences among the relative brain weights in the treated groups $(3,4 \& 5)$ which demonstrated
\end{abstract}

\footnotetext{
${ }^{1}$ Home Economic Devision, Food Technology Department,

Faculty of Agriculture, Cairo University

${ }^{2}$ National Research Center, Giza

${ }^{3}$ Agricultural Research Center - Giza

Received December 2, 2009, Accepted December 30, 2009
}

significantly lower values compared to those in the positive control group.

Key words: cinnamon, propolis, diabetic rats, blood glucose, body weight gain, feed efficiency ratio, relative organs weight.

\section{INTRODUCTION}

Diabetes Mellitus is a chronic condition that occurs when the pancreas does not produce enough insulin or when the body cannot effectively use the produced insulin (WHO, 1999).

Diabetes appeared to be a chronic metabolic disorder characterized by the disturbance in carbohydrate, protein and lipids metabolism. This would be associated with absolute (type1) or relative (type2) deficiencies in insulin secretion and / or insulin action. Hyperglycemia is considered the hall mark of Diabetes Mellitus (Beers and Berkow, 2003 \& Hsu et al., 2003).

Diabetes mellitus might be present with characteristic syndromes such as thirst, polyuria, blurring of vision and weight loss. In the most severe forms, ketoacidosis or a non-ketotic hyperosmolar state might develop and lead to stupor, coma and in absence of effective treatment, death. Often symptoms might be not severe, or absent, and consequently hyperglycemia is sufficient to cause pathological and functional changes that might be present for a long time before the diagnosis is made (American Diabetes Association, 2003).

According to Expert Committee (WHO, 2000), the Eastern Mediterranean Region statistical data recorded the incidence and prediction of diabetes mellitus in the world as well as Egypt. In the World, the numbers of people with diabetes mellitus accounted to 171 million in 2000, and is estimated to reach 300 million at 2030. In Egypt, the numbers of diabetic cases in year 2000 were 2.6 million and is predicted to be about 6.7 million at 2030 .

Currently some spices and plant - based foods were found to play role in glucose metabolism and enhance the overall health of diabetic patients (Broadhurst et al., 2000 \& Kelble, 2005). 
Cinnamon has been used as traditional folk herbs to treat inflammation, as an antioxidant for long time, and recently, it also showed improvement in insulin sensitivity (Kim et al., 2006 \& Roffey et al., 2006). Propolis also has been used as folk medicine since ancient times for its peculiar biological properties and as antioxidant material (Marcucci, 1995, Bankova, 2005, Isla et al., 2005 \& Daugsch, 2007).

Recent articles credit that cinnamon or propolis were used for treating diabetes mellitus (Stefano and Francesco, 2002 \& Fuliang et al., 2005). However the studies concerning the use of them were few with no uniform criteria for the extraction and preparation of these materials in the treatment of diabetes mellitus in rats.

Thus, the present investigation focused on studying the effect of Cinnamon, Propolis ,or their combination on blood glucose levels, body weight, feed efficiency ratio, body weight gain and relative organs' weights in diabetic rats compared to normal ones.

\section{MATERIALS AND METHODS}

\section{Materials:}

\section{Chemicals:}

Casein, vitamins, minerals, cellulose and choline chloride were purchased from El-Gomhoria Company, Cairo, Egypt. While alloxan was purchased from Sigma Company ,Cairo.

\section{Experimental animals:}

Male Albino rats (Sprague Dawley strain) weighted $200 \pm 5 \mathrm{~g}$ were obtained from Research Institute of Ophthalmology, Ministry of Scientific Research, Giza.

\section{Methods:}

\section{Preparation of the experimental diet}

The basal diet consisted of $10 \%$ protein, $10 \%$ corn oil, $5 \%$ cellulose, $1 \%$ vitamin mixture, $4 \%$ salt mixture, $0.2 \%$ choline chloride and $69.8 \%$ corn starch. Both vitamin and salt mixtures were prepared according to A.O.A.C. (1990).

\section{Animals' adaptation}

Male Rats were individually housed in stainless steel wire-bottom cages with water bottles under hygienic conditions and fed on basal diet ad libitum. The experiment was conducted in the animal house of Research Institute of Ophthalmology.

\section{Experimental design}

Thirty Rats were divided into two main groups. The first group (6 rats) was considered as negative control (group 1). The other group of rats (24 rats) was subjected for intravenous injection with alloxan to induce hyperglycemia (Buko et al., 1996).

The diabetic rats were randomly assigned to four equal groups. One of them chosen as positive control (group 2) and the other three groups (3,4 and 5) treated by stomach tube with cinnamon, propolis, or mixture of cinnamon and propolis, respectively. The groups are shown in Table (1).

\section{Induction and treatment of diabetes mellitus}

Diabetes mellitus was induced in rats by the intravenous injection of recrystalyzed alloxan $(150 \mathrm{mg} /$ $\mathrm{kg}$ body weight) dissolved in physiological saline through the tail vena. Normal control rats were given physiological saline only intravenously. Three days later the blood was taken from the tail and the centrifuged serum was tested for blood glucose.

\section{Method of administration}

Cinnamon and propolis were extracted by soaking in water. The concentration of dry material of CINN was about $10 \mathrm{mg} / \mathrm{ml}$, and PROP group was $3 \mathrm{mg} / \mathrm{ml}$, and CINN + PROP group the mixture contained $10 \mathrm{mg}$ cinnamon and $3 \mathrm{mg}$ propolis $/ \mathrm{ml}$. Rats of diabetic groups $(3,4,5)$ were daily given intragastrically the CINN and the PROP and their mixture, respectively for 6 weeks during the experimental period .

\section{Table 1. Groups of animals}

\begin{tabular}{llll}
\hline Group Number & Group name & Treatment \\
\hline Group (1) & Normal (negative) control & Rats were not injected with alloxan. \\
\hline Group (2) & Positive control & Rats & Only injected without treatment. \\
\hline Group (3) & $\begin{array}{l}\text { Cinnamon } \\
\text { ( CINN) }\end{array}$ & were & Rats were given cinnamon extract. \\
\hline Group(4) & Propolis & Rats were given propolis extract. \\
\hline Group (5) & CINN + PROP & with & $\begin{array}{l}\text { Rats were given cinnamon and propolis } \\
\text { extract. }\end{array}$ \\
\hline
\end{tabular}

All Experimental rats were fed on basal diet throughout the experimental period (6 weeks). 


\section{Biological Evaluation:}

During the experimental period (6 weeks), the net food intake was daily recorded, while body weight was weekly recorded. The net food intake and gained body weight were used for the calculation of feed efficiency ratio (FER) as follows:

$($ FER $\%)=\frac{\text { Body weight gain }(\mathrm{g})}{\text { Food intake }(\mathrm{g})} \times 100$

At the end of the experiment, the animals were fasted over night, and then the rats were anaesthetized and sacrified. The different organs of rats (heart, liver, kidney, brain and spleen) were carefully removed, washed in saline solution, dried between 2 filter papers and immediately weighted to estimate relative organs weight. The relative organ weight was calculated as follows:

$$
\begin{aligned}
& \text { Organ weight }(\mathrm{g}) \\
& \text { (Relative organ's weight } \%)=-\mathrm{X} \\
& 100
\end{aligned}
$$

Total body weight (g)

\section{Statistical analysis}

The results are presented as the mean \pm S.D. Data were analyzed using SPSS soft ware program (2009). Comparisons between means of the control and treated groups were analyzed by Student's T-test and their significance at $(\mathrm{p}<0.05, \mathrm{p}<0.01$ and $\mathrm{p}<0.001)$ .Comparisons among the diabetic rats were established by ANOVA variance analysis. Least significant differences (L.S.D) were considered statistically significant at $P<0.05$. (Freed et al., 1989).

\section{RERSULTS AND DISCUSSION}

Effect of different treatments (cinnamon, propolis and their combination) on body weight gain (BWG $\%$ ) and feed efficiency ratio (FER) in normal and diabetic rats:

Body weights as well as body weight gain and feed efficiency ratio in the different groups of rats before and after the induction of diabetes and the administration of cinnamon, propolis, or their combination in diabetic rats were compared with normal rats are shown in Table (2).

Each value represents the mean \pm S.D. Student's $T$ test, the significance of the difference between treatment groups and control group $(* * P<0.01$ and $* * * P<$ $0.001)$; means in the same column not sharing a common subscript letter (a, b, c and d) are significantly different $(P<0.05)$ between treatment groups.

Regarding final body weights of rats (after 6 weeks), there was a very highly significant difference $(\mathrm{p}<0.001)$ between positive control and negative control group.

While, body weights of normal control group rats were significantly higher than the three treated groups $(\mathrm{p}<$ 0.01). The administration of cinnamon, propolis \& their combination showed an improvement in final body weights of diabetic rats compared to those without the administration (positive control). No significant differences were found among rats body weights of treated groups (3, 4 and 5).

Body weight gains and feed efficiency ratios were decreased in the positive control group when compared

\begin{tabular}{|c|c|c|c|c|}
\hline Groups & $\begin{array}{c}\text { Initial body weights } \\
\text { gm }\end{array}$ & $\begin{array}{c}\text { Final body weights } \\
\text { gm }\end{array}$ & BWG\% & FER \\
\hline $\begin{array}{l}\text { Normal } \\
\text { control (1) }\end{array}$ & $203.00 \pm 2.00$ & $295.60 \pm 1.52$ & $49.49 \pm 0.65$ & $0.15 \pm 0.01$ \\
\hline $\begin{array}{l}\text { Positive } \\
\text { control (2) }\end{array}$ & $201.00 \pm 1.00$ & $259.33 \pm 2.08^{* * *}, \mathrm{~b}$ & $28.83 \pm 2.51 * * *, b$ & $0.09 \pm 0.01 * * *, \mathrm{~b}$ \\
\hline $\begin{array}{l}\text { Group(3) } \\
\text { CINN }\end{array}$ & $202.33 \pm 2.56$ & $283.20 \pm 3.01 * *, a$ & $39.40 \pm 2.83 * *, \mathrm{a}$ & $0.13 \pm 0.01 * *, \mathrm{a}$ \\
\hline $\begin{array}{l}\text { Group(4) } \\
\text { PROP } \\
\end{array}$ & $204.00 \pm 1.50$ & $286.83 \pm 3.25 * *, a$ & $40.50 \pm 2.28 * *, a$ & $0.14 \pm 0.01 * *, a$ \\
\hline $\begin{array}{l}\text { Group(5) } \\
\text { CINN+PRO }\end{array}$ & $203.66 \pm 1.52$ & $288.00 \pm 4.35 * *, \mathrm{a}$ & $41.54 \pm 3.04 * *, \mathrm{a}$ & $0.14 \pm 0.01^{* *}, \mathrm{a}$ \\
\hline LSD & 3.63 & 6.72 & 5.30 & 0.003 \\
\hline
\end{tabular}

Table 2. Effect of different treatments (cinnamon, propolis ,or their combination) on body weight gain (BWG\%) and feed efficiency ratio (FER) in normal and diabetic rats

BWG : Body weight gain percent

FER : Feed efficiency ratio. 
to that of the normal control group $(28.83 \pm 2.51$ vs. $49.49 \pm 0.65)$ and $(0.09 \pm 0.01$ vs. $0.15 \pm 0.01)$, respectively. Treating diabetic groups with cinnamon, propolis or their combinations recorded significant increases in feed efficiency ratios, compared to that for untreated group. When diabetic rats were treated with cinnamon, propolis and their combination, the body weight gains were higher than that of positive control group. The capability of these treatments to protect body weight loss might be ascribed to the efficiency of such materials to reduce hyperglycemia.

In this respect, Ramesh and Pugalendi (2006) observed a decrease in body weight of the diabetic rats and attributed that to the loss or degradation of structural proteins resulting from diabetes.

Effect of cinnamon, propolis and their combination on relative organs` weight ( $\mathrm{ROW} \%)$ :

The effect of cinnamon, propolis and their combination on relative organs' weight (ROW \%) is illustrated in table (3).

Concerning liver, the results showed that, there were no significant differences among the treated groups (3, 4 and 5). While, there were significant differences between relative liver weights of positive control and normal control group at $(\mathrm{P}<0.001)$ as well as the treated groups at $(\mathrm{P}<0.05)$. The mean of normal control group significantly showed the lowest value. As there were significant increases in the relative liver weights of the diabetic rats when compared with the normal control group. The relative liver weights in the diabetic rats after the administration of propolis and /or cinnamon were significantly lower than those for positive control diabetic rats without such administration.
The administration of either cinnamon or propolis and their combination decreased the adverse effect of diabetes mellitus on liver weight. Diabetes mellitus is one of the most common causes of fatty liver and the frequent increase in the liver size in patients with diabetes mellitus was recognized (Nanji et al., 1986).

The accumulation of fat into the hepatocytes might lead to increase in liver weight, or hepatomegaly might occur due to glycogen deposition or fatty metamorphosis in the chronic phase of diabetes (Kume et al., 1994).

However, there were insignificant differences among the mean values of relative weights for kidney, heart and spleen in the treated groups (group 3, 4 and 5 ).while these values were significantly lower than that of the diabetic control group $(\mathrm{p}<0.05)$.

The relationship between diabetes and increased kidney weight was supported by (Craven et al., 1997). In diabetic nephropathy, increased intraglomular pressure due to renal glomular vascular lesions induced microalbuminuria. With further advances in this lesion apparent and persistent protenuria due to glomular sclerosis occurs leading to deterioration of renal function and chronic renal failure (Itoh et al., 2002).

Further studies assured that the kidneys of patients with diabetes mellitus were larger than those of control subjects. Good metabolic control at onset of diabetes appears to be capable of reversing kidney enlargement (Wayne et al., 2004).

Table 3 . Effect of cinnamon, Propolis and their combination on relative organs' weights of normal and diabetic rats

\begin{tabular}{lccccc}
\hline \multicolumn{1}{c}{ Group } & Liver & Spleen & Kidney & Heart & Brain \\
\hline $\begin{array}{l}\text { Normal } \\
\text { Control (1) }\end{array}$ & $2.79 \pm 0.03$ & $0.15 \pm 0.01$ & $0.59 \pm 0.005$ & $0.25 \pm 0.01$ & $0.50 \pm 0.01$ \\
\hline $\begin{array}{l}\text { Positive } \\
\text { Control (2) }\end{array}$ & $3.36 \pm 0.04^{* * *}, \mathrm{~b}$ & $0.21 \pm 0.02^{* * *}, \mathrm{~b}$ & $0.72 \pm 0.007 * * *, \mathrm{~b}$ & $0.36 \pm 0.02 * * *, \mathrm{~b}$ & $0.78 \pm 0.01 * * *, \mathrm{~b}$ \\
\hline $\begin{array}{l}\text { Group(3) } \\
\text { CINN }\end{array}$ & $3.04 \pm 0.12^{*}, \mathrm{a}$ & $0.15 \pm 0.01 \mathrm{a}$ & $0.66 \pm 0.005 \mathrm{a}$ & $0.23 \pm 0.03 \mathrm{a}$ & $0.63 \pm 0.01^{* *}, \mathrm{a}$ \\
\hline $\begin{array}{l}\text { Group(4) } \\
\text { PROP }\end{array}$ & $2.93 \pm 0.05^{*}, \mathrm{a}$ & $0.15 \pm 0.01 \mathrm{a}$ & $0.64 \pm 0.04 \mathrm{a}$ & $0.20 \pm 0.03 \mathrm{a}$ & $0.66 \pm 0.02^{* *}, \mathrm{a}$ \\
\hline $\begin{array}{l}\text { Group(5) } \\
\text { CINN+PRO }\end{array}$ & $2.91 \pm 0.11^{*} \mathrm{a}$ & $0.14 \pm 0.01 \mathrm{a}$ & $0.63 \pm 0.02 \mathrm{a}$ & $0.21 \pm 0.02 \mathrm{a}$ & $0.60 \pm 0.02^{*}, \mathrm{a}$ \\
\hline LSD & 0.16 & 0.03 & 0.04 & 0.03 & 0.07 \\
\hline
\end{tabular}

Each value represents the mean \pm S.D.; Student's $T$-test, the significance of the difference between treatment groups and control group $(* P<0.05$, $* * P<0.01$ and $* * * P<0.001)$; means in the same column not sharing a common subscript letter (a, b, c) are significantly different $(P<0.05)$ between treatment groups. 
With regard to relative brain weight, normal control group showed significantly higher value compared to those of the other groups; group2 $(\mathrm{p}<0.001)$, group3\&4 $(\mathrm{p}<0.01)$ and group5 $(\mathrm{p}<0.05)$. While there were insignificant differences among the relative brain weights in the treated groups (3,4 and 5) which demonstrated significantly lower values compared to those in the positive control group.

Hypoglycemic effect of cinnamon, propolis and their combination on glucose levels of diabetic and normal rats.

Blood glucose levels before and after the induction of diabetes compared to normal rats illustrated in Table (4).

Changes in blood glucose levels after administration of cinnamon, propolis and their combination in rats with induced diabetes mellitus compared with normal rats were illustrated in Figure (1).

Before injection there were no significant differences among blood glucose levels of all the experimental groups. While there were very highly significant differences $(p<0.001)$ at the beginning of the experiment between glucose levels of positive control (diabetic group) and the normal control group $(398.60 \pm 1.24 \mathrm{vs}$. $76.83 \pm 0.47 \mathrm{mg} / \mathrm{dl}) \quad$ Similarly, there were highly significant differences $(\mathrm{P}<0.001)$ between glucose level means of negative control and those of all the treated groups $(3,4$ and 5), which were $399.03 \pm 1.05, \quad 401.00 \pm 1.00$ and $397.73 \pm 2.05 \mathrm{mg} / \mathrm{dl}$, respectively.

From the same table, it is obvious that after 2 weeks as well as 6weeks, differences among the treated groups $(3,4,5)$, positive control (group2) and normal control group were highly significant ( $\mathrm{p}<0.001)$.After 2 weeks, blood glucose levels for the three treated groups represented $(275.36 \pm 1.40,215.80 \pm 1.33,211.10 \pm 1.04$ $\mathrm{mg} / \mathrm{dl}$ ) in ascending order.

However, glucose levels were $350.50 \pm 1.55$ and $79.43 \pm 0.51 \mathrm{mg} / \mathrm{dl}$ for positive control and negative control groups, respectively. Moreover, extending the period up to 6 weeks resulted in an additional highly significant decrease. Values were $(151.83 \pm 1.55$, $145.06 \pm 1.10,140.33 \pm 1.52,372.33$. \pm 1.55 and 72.60 $\pm 0.52 \mathrm{mg} / \mathrm{dl})$ for the groups $(3,4,5$ and 2$)$ in respective order..

These data revealed that, the most efficient effect on reducing glucose level occurred by administrating the combination of cinnamon and propolis (group5) for 2 and 6 weeks at $(\mathrm{P}<0.001)$. Following it, propolis treatment (group4) and then group 3 (cinnamon) which had the lowest efficient effect at the same probability $(\mathrm{p}<0.001)$ compared with the control.

The decline in blood glucose levels reached its maximum level after 6 weeks. These findings could be attributed to the hypoglycemic effect of cinnamon and/ or propolis. These extracts might have a regulatory role in blood glucose level and it may also exert a blood glucose-suppressing effect by improving insulin sensitivity or slowing absorption of carbohydrates in the small intestines.

Concerning propolis ,these findings are in the same line of those noted by Wang and Li (2004) who found that shayo Gango-tang (PSG) and or propolis ethanol extract showed significant reductions $(\mathrm{p}<0.05)$ in blood sugar levels of diabetic rabbits compared to control group diabetic rabbits. Fuliang et al., (2005) also reported that, both ethanol and water extracts of propolis

Table 4. Hypoglycemic effect of cinnamon, propolis and their combination on blood glucose levels of diabetic and normal rats

\begin{tabular}{lcccc}
\hline \multirow{2}{*}{ Groups } & \multicolumn{4}{c}{ Blood glucose level (mg/dl) } \\
\cline { 2 - 5 } & Before injection & After injection & After 2weeks & After 6weeks \\
\hline Normal control (1) & $70.16 \pm 1.04$ & $76.83 \pm 0.47$ & $79.43 \pm 0.51$ & $72.60 \pm 0.52$ \\
\hline Positive control (2) & $69.83 \pm 0.56$ & $398.60 \pm 1.24 * * *, \mathrm{a}$ & $350.50 \pm 1.55^{* * *}, \mathrm{~d}$ & $372.33 \pm 2.51 * * *, \mathrm{~d}$ \\
\hline Group(3) CINN & $71.76 \pm 0.35$ & $399.03 \pm 1.05^{* * *}, \mathrm{a}$ & $275.36 \pm 1.40^{* * *}, \mathrm{c}$ & $151.83 \pm 1.55^{* * *}, \mathrm{c}$ \\
\hline Group(4) PROP & $70.30 \pm 0.45$ & $401.00 \pm 1.00^{* * *}, \mathrm{a}$ & $215.80 \pm 1.33^{* * *}, \mathrm{~b}$ & $145.06 \pm 1.10^{* * *}, \mathrm{~b}$ \\
\hline Group(5) & $70.20 \pm 1.19$ & $397.73 \pm 2.05^{* * *}, \mathrm{a}$ & $211.10 \pm 1.04^{* * *}, \mathrm{a}$ & $140.33 \pm 1.52^{* * *}, \mathrm{a}$ \\
CINN+PROP & $\mathbf{2 . 1 9}$ & $\mathbf{3 . 7 1}$ & $\mathbf{1 . 5 3}$ & $\mathbf{4 . 0 4}$ \\
\hline LSD & & &
\end{tabular}


Each value represents the mean \pm S.D. Student's $T$-test, the significance of the difference between treatment groups and control group $(* * * P<0.001)$; means in the same column not sharing a common subscript letter (a, b, c and d) are significantly different $(P<0.05)$ between treatment groups.

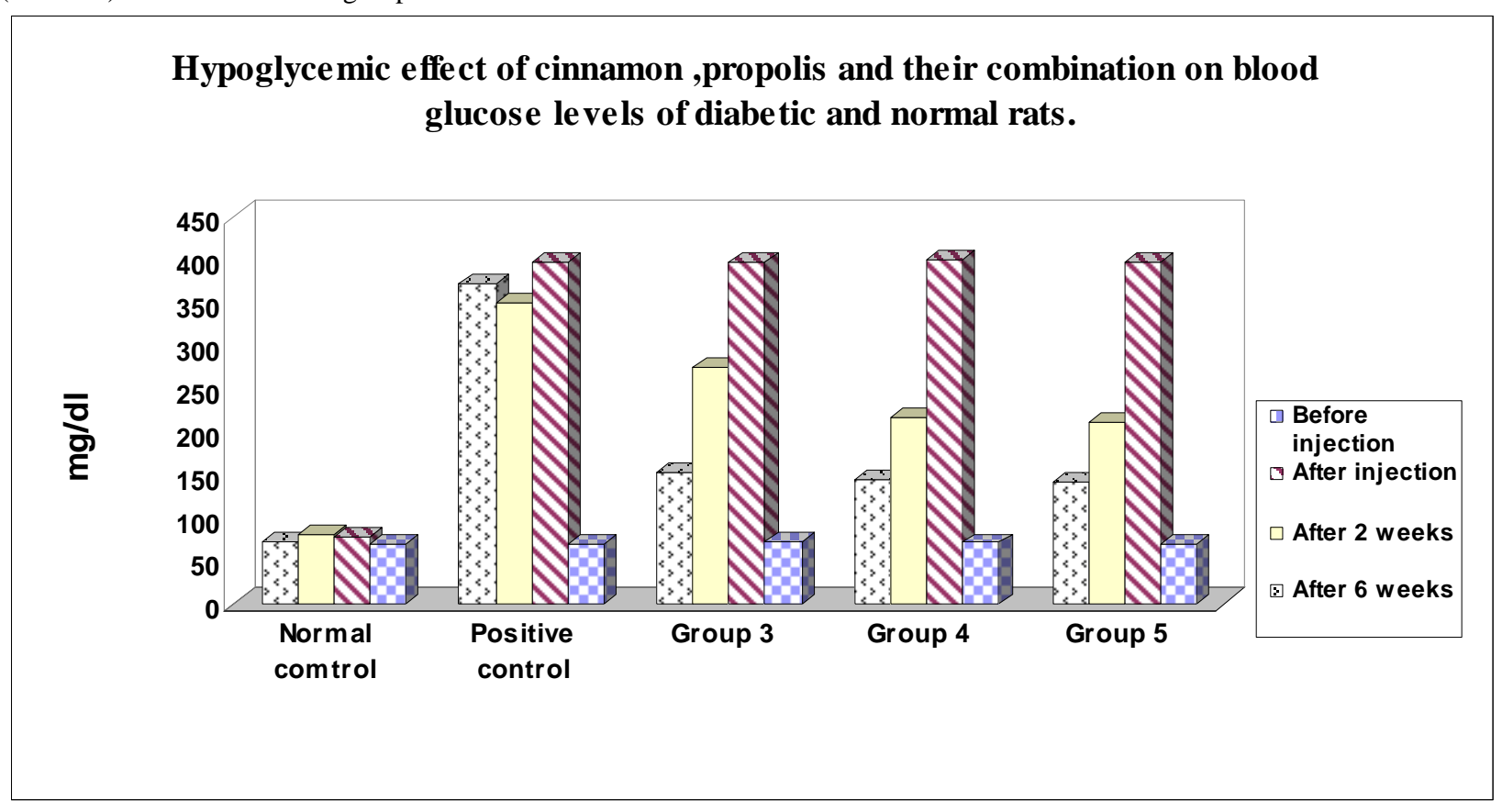

Figure 1. Hypoglycemic effect of cinnamon, propolis and their combination on blood

\section{glucose levels of diabetic and normal rats}

led to decrease the levels of blood glucose in rats with diabetes mellitus suggesting that Propolis can control blood glucose and modulate its metabolism The anti-diabetic effect of cinnamon extract in type 2 diabetic animal model was also noticed by Kim et al., (2006). Blood glucose concentration was significantly decreased in a dose dependent manner $(p<0.001)$ with the most in the maximum dose $(200 \mathrm{mg} / \mathrm{kg})$ group compared with the control. Cinnamon extract seemed to have a moderate effect in reducing fasting plasma glucose concentrations in diabetic patients (Mang et al., 2006).

The recent study of Hlebowicz, et al., (2007) proved that, the intake of $6 \mathrm{~g}$ cinnamon with rice pudding reduced postprandial blood glucose and delayed gastric emptying without affecting satiety. Similarly, Striffler et al., (2007) indicated that acute cinnamon dosing caused a marked improvement of impaired glucose tolerance accompanied by significant increases in rates of insulin secretion in this diabetic animal model.

\section{REFERENCES}

American Diabetes Association (2003). Diabetic nephropathy, Diabetes Care, 26 (1) : S94-S98.

A.O.A.C.(1990). Official Methods of Analysis of Association of Official Analytical Chemist, $15^{\text {th }}$ ed.Pub by
Association of Official Analytical Chemists, Arlington, West Verginia,USA.

Bankova, V (2005) .Recent trends and important developments in propolis research. Evidence -based Compl. and Alt. Medicine .Vol.2 (1): 29-32.

Beers,M.H. and Berkow , R. (2003). Endocrine and metabolic disorders of carbohydrate metabolism, Merck Manual of Diagnosis and Therapy, Home Edition (on line). $17^{\text {th }}$ edition, Chaps.6-18.

Broadhurst, C.L.;Polansky,M.M.; Anderson, R.A. (2000). Insuline - like biological activity of culinary and medicinal plant aqueous extracts in vitro.J.Agri.Food.Chem., 48:849-852.

Buko,V.;Lukivskaya,O.;Tarasov,Y.,Zavodnik,L.;Borodasky,A ;;Goren,S.B.;Janz,B.and Gundermann,K.J.(1996).Hepatic and pancreatic effect of polyphenol phatidyl choline in rats with alloxan- induce diabetes,Cell.Biochem.Funct.,14(2):131-137.

Craven ,P.A.;Derubertis,F.R.; Kagan,V.E.; Melhem,M.and Studer,R.K.(1997). Effects of supplementationwith vitamin $\mathrm{C}$ or $\mathrm{E}$ on albuminuria, glomular TGF-B1, and Glumular size in diabetes. J.Am.Soc.Nephrol. 8: 14051411.

Daugsch,A.;Moraes,C.S.;Fort,P.andPark,Y.K.(2007).Brazilian Red Propolis-Chemical Composition and Botanical Origin.Evidence- based Compl.and Alt.Medicine, 5:1-13.

Freed, R. S.P ;.Einensmith,S.; Gutez,D.;Reicosky,V.W.; Smail and Wolberg, P (1989). User's guide to MSTAT-C 
Analysis of Agronomic Research Experiments.Michigan State University, East Lansing,USA.

Fuliang,H.U.;Hepburn,H.R.;Hongzhuan, X.; Minli,C.S.;Daya, S. and Radloff, S.E.(2005). Effect of Propolis on blosod glucose, blood lipid and free radicals in rats with diabetes mellitus, Pharmacological Research, 51(2): 147-152.

Hlebowicz,J.;Darwich,G.;Bjorgell,O.andAlmer,L.O.(2007). Effect of Cinnamon postprandial blood glucose, gastric emptying, and satiety in healthy subjects, Am.Journ.of Clin.Nutr.,85(6):1552-1556.

Hsu,C.S.; Chiu, W.C.andYeh, S.L.(2003). Effect of soy isoflavone supplementationonplasma glucose, lipids and antioxidant enzyme activities in streptozotocin- induced diabetic rats, Nutr. Res., 2367-75.

Isla,M.I.;Paredes - Guzman, J.F., NievaMoreno, M.I.;Koo, H.; Pak, Y.K. (2005). Some chemical composition and biological activity of Northern Argentine propolis, J. Agric. Food Chem.. 53: 11661172.

Itoh,Y.;Imamura,S.;Yamamoto,K.;Ono,Y.;Nagata,M.;Kobaya shi,T.; Kato ,T.;Tomita,M.;Nakai,A.; Itoh, M. and Nagasaka,A.(2002).Changes of endothelin in streptozotocin-induced diabetic rats: effect of an angiotensin converting enzyme inhibitor,enalapril maleate,Journal of Endocrinology,175,233-239.

Kelble,A.(2005).Spices and type 2 diabetes ,Nutrition \& Food Science.35(2):81-87.

Kim, S.H.; Hyun,S.H; and Choung, S.Y.(2006).Anti-diabetic effect of cinnamon extract on blood glucose in $\mathrm{db} / \mathrm{db}$ mice, J.of Ethnopharmacology,104(1): 119-123.

Kume ,E.;Ohmachi,Y.;Hagaki,S.;Tamura,K. and Doi,K.(1994).Hepatic changes of mice in sub acute phase of streptozotocin induced diabetes,Exp.Toxicol.Pathol.46:368-374.

Mang, B.; Wolters,M.;Schmitt, B.; Kelb, K.; Lichtinghagen, R., Stichtenoth, D. and Mahan,A.(2006). Effect of a cinnamon extracts on plasma glucose, $\mathrm{HbA}$, and serum lipids in diabetes mellitus type 2, Eur.J.Clin.Invest.36 (5): 340-344.

Marcucci, M.C . (1995) . Propolis: chemical composition,biological properties and therapeutic activity.Apidologie, 26:83-99.

Nanji ,A.A.; French, S.W.and Freeman,J.B.(1996). Serum Alanine Aminotransferases Ratio and Degree of Fatty Liver in Morbidity Obese Patients. Enzyme,36:266-269.

Ramesh,B.and Pugalendi,K.V.(2006).Antihyperglycemic effect of Umbelliferone in streptozotocin-diabetic rats,J.Med.Food.9(4):562-566.

Roffey,B;Atwal, A. and Kubow, S. (2006).Cinnamon water extracts increase glucose uptake but inhibit adiponectin secretion in 3T3-L1 adipose cells. Molecular Nutrition \& Food Research.50 (8):739-745.

SPSS (2009) .SPSS for Windows, version 17.0 SPSS Inc.,Chicago,USA.

Stefano,C.and Francesco,C.(2002).Propolis and old remedy used in modern medicine.Fitoterapia,73:1-6.

Striffler,J.S.;Polansky,M.M.andAnderson,R.A.(2007).Cinnam on administration enhances glucose-induced insulin secretion in diabetic rats, The FASEB Journal.21:845850 .

Wang,N.Z.and Li,D.(2004).Effect of combined propolisethanol-extract and Shaoyao-Gancao-tang on blood sugar levels in rabbits with alloxan induced experimental diabetes, Asia Pac.J.Clin.Nutr.,13:66-69.

Wayne, D.C.; Tanya, M.O.; Malcom,C.; Richard, J.M and George,J.(2004).Earlier detection of microalbuminuria in diabetic patients using a new urinary albumin assay. Kidney International: 65:1850-1855.

WHO (1999). World Health Organization, Definitions, Diagnosis and Classification of diabetes mellitus and its complications. WHO, Geneva, Switherland.

WHO (2000). Diabetes Mellitus (Tech.Rep.Ser.646), $2^{\text {nd }}$ Rep . Expert Committee WHO. Geneva, Switzerland 


\section{الملخص العربي}

\section{تاثير القرفة وصمغ النحل وخليطهما عل مستوى جلو كوزالدم، ووزن الجسم ومعدل كفاءة

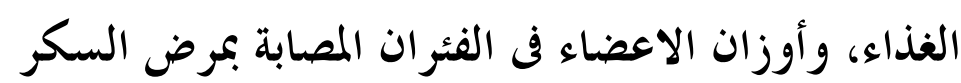

غادة محمدى الخرباوى، شريف جمال نوب، هناء محمد عبد العزيز، شفيقة عبد الحميد زكى

أظهرت النتائج أن المعاملة بكل من القرفة وصمغ النحل وخليطيهما قد أدى إلى إنخفاض ملحوظ في مستويات الجلوكوز فن

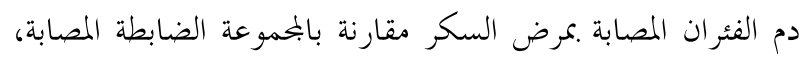
وأن أفضل المعاملات هى الخليط من القرفة وصمغ النحل. كما تبين

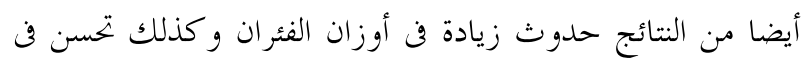
أوزان الأعضاء وذلك مقارنة بالبمموعة الضابطة المصابة. أما بالنسبة

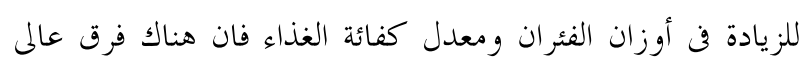
المعنوية بين البمموعة الضابطة غير المصابة والمحموعة الضابطة المصابة

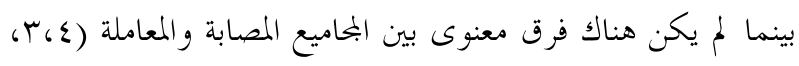
ه).كما وجد أنه لا توجد فروق معنوية فن الوزن النسبى للكبد بين

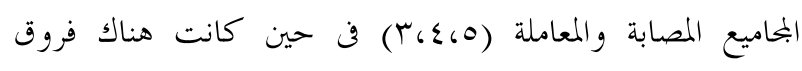
معنوية في الأوزان النسبية للكلى والقلب والطحال لتلك البحاميع المصابة والمعاملة عند مقارنتها بالمحموعة الضابطة الغير مصابة. أما بالنسبة للوزن النسبى للمخ فقد أظهرت المحموعة الضابطة غير

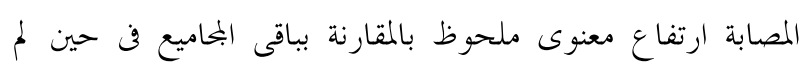

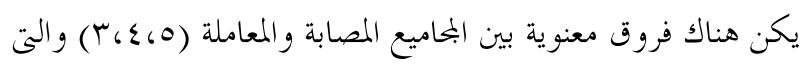
اظهرت قيما أقل عند مقارنتها بالمحموعة الضابطة المصابة.
صممت هذه التجربة لدراسة تأثير كل من القرفة وصمغ النحل وخليطهما على مستوى الجلوكوز في دم فئران التجارب المصابة بالسكر. و كذلك على الزيادة في أوزاهم والأوزان النسبية لأعضاء الفئران المصابة مقارنة بالفئران الطبيعية. أجريت الدراسة على · بأفر من نوع الالبينو تم تقسيم الفئران

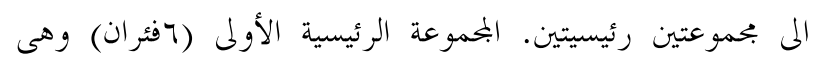
(بحموعة ) البمموعة الضابطة غير المصابة، أما البحموعة الرئيسية

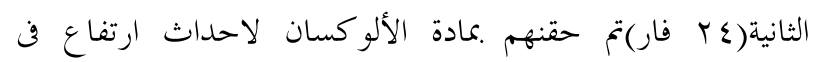
مستوى الجلوكوز في الدم.وقد قسمت البمموعة المصابة بارتفاع

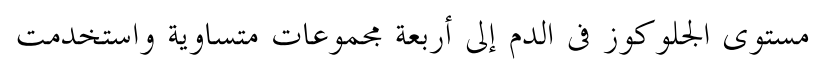
إحداهما كمجموعة ضابطة مصابة(بحموعة r))، أما باقى المحاميع فقد استخدمت الأنبوبة المعدية عن طريق الفم للثلاث بجموعات

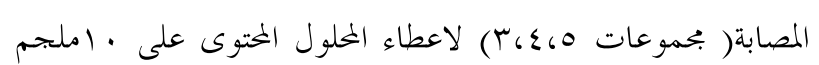

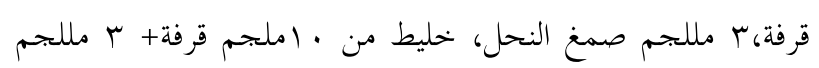

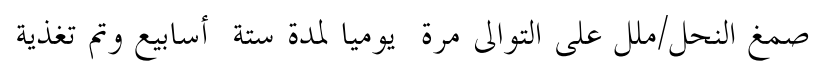
جميع البمموعات على الغذاء الاساسى. 